\title{
Thionine-Bromate as a New Reaction System for Kinetic Spectrophotometric Determination of Hydrazine in Cooling Tower Water Samples
}

\author{
Masoud Reza Shishehbore, Ali Sheibani, and Masoumeh Eslami \\ Department of Chemistry, Yazd Branch, Islamic Azad University, P.O. Box 89195-155, Yazd, Iran \\ Correspondence should be addressed to M. Reza Shishehbore; shishehbor47@gmail.com
}

Received 22 June 2012; Revised 22 July 2012; Accepted 9 August 2012

Academic Editor: Shayessteh Dadfarnia

Copyright (C) 2013 M. Reza Shishehbore et al. This is an open access article distributed under the Creative Commons Attribution License, which permits unrestricted use, distribution, and reproduction in any medium, provided the original work is properly cited.

\begin{abstract}
A simple, selective, and inexpensive kinetic method was developed for the determination of hydrazine based on its inhibitory effect on the thionine-bromate system in sulfuric acid media. The reaction was monitored spectrophotometrically at $601 \mathrm{~nm}$ by a fixed time method. The effect of different parameters such as concentration of reactants, ionic strength, temperature, and time on the rate of reaction was investigated, and the optimum conditions were obtained. Under optimum conditions, the calibration curve was linear in the concentration range from $0.8-23.0 \mu \mathrm{g} \mathrm{mL} L^{-1}$ of hydrazine, and the detection limit of the method was $0.22 \mu \mathrm{g} \mathrm{mL}$. The relative standard deviation for five replicate determinations of $1.0 \mu \mathrm{g} \mathrm{mL}^{-1}$ of hydrazine was $0.74 \%$. The potential of interfering effect of foreign species on the hydrazine determination was studied. The proposed method was successfully applied for the determination of hydrazine in different water samples.
\end{abstract}

\section{Introduction}

Hydrazine is a strong reducing agent that is used as an oxygen scavenger in boilers. Hydrazine and its derivatives are also used widely in industry and agriculture as fuel in rockets and fuel cells, antioxidant, corrosion inhibitor, catalyst, emulsifier, insecticide and pesticide, plant-growth regulator, photographic developer, dyes stuff, explosive, and blowing agent for plastics [1-3]. Hydrazine that can be absorbed through skin has carcinogenic and hepatotoxic effects. It affects the liver, the kidney, and the brain; therefore, it is important in pharmacology. Furthermore, hydrazine is suspected of being a mutagen and carcinogenic compound [4]. Since the toxicity of hydrazine is well known, a sensitive and accurate method requires for the determination of trace amounts of hydrazine in different samples.

Various instrumental methods were used for the determination of hydrazine. These include chromatography $[5,6]$, capillary electrophoresis [7], voltammetry [8, 9], spectrophotometry [10], spectrofluorimetry [11], chemiluminescence [12], potentiometry [13], and amperometry [14]. Some of these methods have limitations such as hard operation and high cost. Catalytic spectrophotometric methods, because of their excellent sensitivity, sufficient accuracy, simple procedure, and inexpensive apparatus, are more attractive for the determination of hydrazine and a large group of compounds in different matrices [15-24].

In this paper, a kinetic spectrophotometric method was developed for the determination of hydrazine based on its inhibitory effect on the reaction of bromate with thionine in acidic media. The developed method surpasses reported kinetic spectrophotometric methods in the linear dynamic range $[20,22-24]$ and detection limit $[19,21]$ for hydrazine determination. However, lower detection limit [18] and wider linear dynamic range [21] were also reported. The method has been successfully applied for the determination of hydrazine in different water samples.

\section{Experimental}

2.1. Reagents and Chemicals. Doubly distilled water and analytical grade chemical reagents were used. The hydrazine 
solution $\left(200.0 \mu \mathrm{g} \mathrm{mL}^{-1}\right)$ was prepared by dilution of concentrated hydrazine ( $a=80 \%, d=1.03 \mathrm{~g} \mathrm{~mL}^{-1}$, Merck) to $250 \mathrm{~mL}$ with water as daily. A solution of Thionine $\left(300.0 \mu \mathrm{mol} \mathrm{L}^{-1}\right)$ was prepared by dissolving $0.0862 \mathrm{~g}$ of thionine (Merck) in water and diluting to $1000 \mathrm{~mL}$ in a volumetric flask. Sulfuric acid solution $\left(4.0 \mathrm{~mol} \mathrm{~L}^{-1}\right)$ was prepared by diluting $217.4 \mathrm{~mL}$ of concentrated sulfuric acid ( $a=98 \%, d=1.84 \mathrm{~kg} \mathrm{~L}^{-1}$, Merck) to $1000 \mathrm{~mL}$. A potassium bromate solution $\left(50.0 \mathrm{mmol} \mathrm{L}^{-1}\right)$ was prepared by dissolving $8.3540 \mathrm{~g}$ of potassium bromate (Merck) in water and diluting to $1000 \mathrm{~mL}$ in a volumetric flask.

2.2. Apparatus. A Shimadzu UV-VIS spectrophotometer (160-A, Japan) with $1 \mathrm{~cm}$ matched glass cells was used to measure the absorbance. A thermostated water bath (Heidolph, Germany) was used to keep the reaction at desired temperature. A stopwatch was applied to record the reaction time.

2.3. General Procedure. The inhibited reaction was studied spectrophotometrically by monitoring the change in absorbance of the reaction mixture at $601 \mathrm{~nm}$. For this purpose, to a series of $10 \mathrm{~mL}$ volumetric flasks, $1.9 \mathrm{~mL}$ of $4.0 \mathrm{~mol} \mathrm{~L}^{-1}$ sulfuric acid solution, $1.2 \mathrm{~mL}$ of $300.0 \mu \mathrm{mol} \mathrm{L}^{-1}$ thionine solution, and the sample or standard solutions containing 8.0-230.0 $\mu \mathrm{g}$ of hydrazine were added. The solution was mixed and diluted to $8 \mathrm{~mL}$ with water. Then, $0.08 \mathrm{~mL}$ of $50.0 \mathrm{mmol} \mathrm{L}^{-1}$ bromate solution was added and diluted to the mark. The solution was mixed thoroughly and a portion of it was transferred to a glass cell. The absorbance of inhibited reaction $\left(\Delta A_{s}\right)$ was measured against water at $601 \mathrm{~nm}$ for time interval $0.5-2.5 \mathrm{~min}$. The measurement in the absence of hydrazine was repeated to obtain the values for the uninhibited reaction $\left(\Delta A_{b}\right)$. Finally, the difference in the absorbance change was considered as the response $(\triangle A=$ $\left.\Delta A_{b}-\Delta A_{s}\right)$.

\section{Results and Discussion}

Figures 1(a) and 1(b) show the absorption spectra of the reaction mixture (sulfuric acid, thionine, and bromate) in presence and absence of hydrazine, respectively. Since the absorbance change was reduced signficantly in presence of hydrazine, the proposed reaction system can be used for the determination of hydrazine. The possible mechanism of the reactions can be described as follows:

$$
\begin{gathered}
\mathrm{BrO}_{3}{ }^{-}+\mathrm{H}^{+}+\text {Thionine }(\mathrm{Red}) \longrightarrow \mathrm{Br}^{-}+\text {Thionine }(\mathrm{Ox}) \\
\mathrm{BrO}_{3}^{-}+\mathrm{H}^{+}+\mathrm{Br}^{-} \longrightarrow \mathrm{Br}_{2}+\mathrm{H}_{2} \mathrm{O} \\
\mathrm{Br}_{2}+\mathrm{H}^{+}+\text {Thionine (Red) } \longrightarrow \mathrm{Br}^{-}+\text {Thionine }(\mathrm{Ox})
\end{gathered}
$$

where Red is the reduced form and Ox is the oxidized form of reactant. The presence of reducing agents that react slowly with bromate but rapidly with bromine inhibits the decolorizing reaction. According to the following reaction,

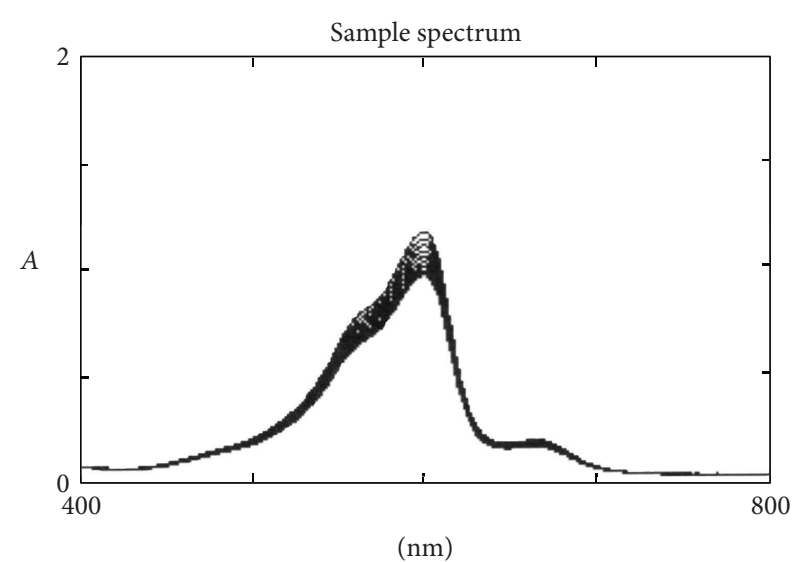

(a)

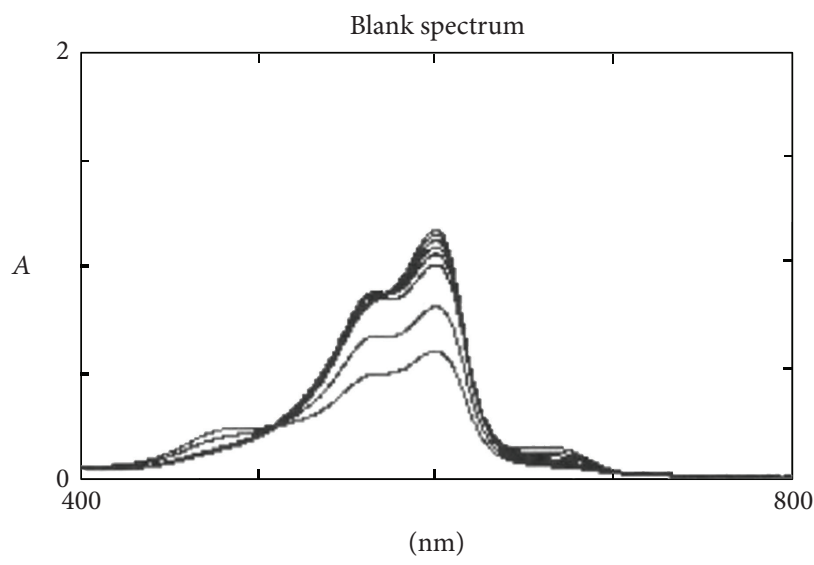

(b)

Figure 1: Absorption spectra of (a) inhibited and (b) uninhibited reactions. Conditions: sulfuric acid, $0.5 \mathrm{~mol} \mathrm{~L}^{-1}$; thionine, $30.0 \mu \mathrm{mol} \mathrm{L}^{-1}$; hydrazine, $2.0 \mu \mathrm{g} \mathrm{mL}^{-1}$; bromate, $0.5 \mathrm{mmol} \mathrm{L}^{-1} ; 25^{\circ} \mathrm{C}$ and $4.0 \mathrm{~min}$.

hydrazine reacts with bromine and causes an inhibitory effect on the decolorization of Thionine by bromine.

$$
\mathrm{Br}_{2}+\mathrm{H}^{+}+\text {Hydrazine }(\mathrm{Red}) \longrightarrow \mathrm{Br}^{-}+\text {Hydrazine }(\mathrm{Ox}) \text {. }
$$

The level of inhibition depends on the amount of hydrazine in the reaction mixture. Therefore, this behavior allows developing an analytical method for the determination of hydrazine.

3.1. Effect of Variables. The effective parameters on the reaction rate including the reagents concentration, ionic strength, temperature, and time must be optimized to take full advantages. For this purpose, each parameter was optimized by setting other parameters constant. The maximum difference between the blank and sample absorbance change $(\Delta A)$ was considered to obtain more sensitive results.

The influence of sulfuric acid concentration on the sensitivity was investigated in the range from $0.4-1.0 \mathrm{~mol} \mathrm{~L}^{-1}$ (Figure 2). The results show that the response was increased with increasing the sulfuric acid concentration up to 


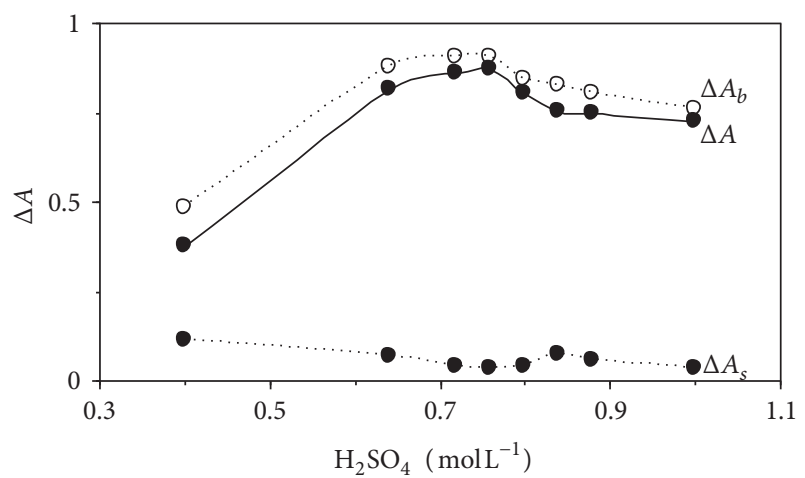

FIGURE 2: Effect of sulfuric acid concentration on the rate of uninhibited $\left(\Delta A_{b}\right)$ and inhibited $\left(\Delta A_{s}\right)$ reaction and response $(\triangle A)$. Conditions: thionine, $30.0 \mu \mathrm{mol} \mathrm{L}^{-1}$; hydrazine, $2.0 \mu \mathrm{g} \mathrm{mL}^{-1}$; bromate, $0.5 \mathrm{mmol} \mathrm{L}^{-1} ; 25^{\circ} \mathrm{C}$ and $4.0 \mathrm{~min}$.

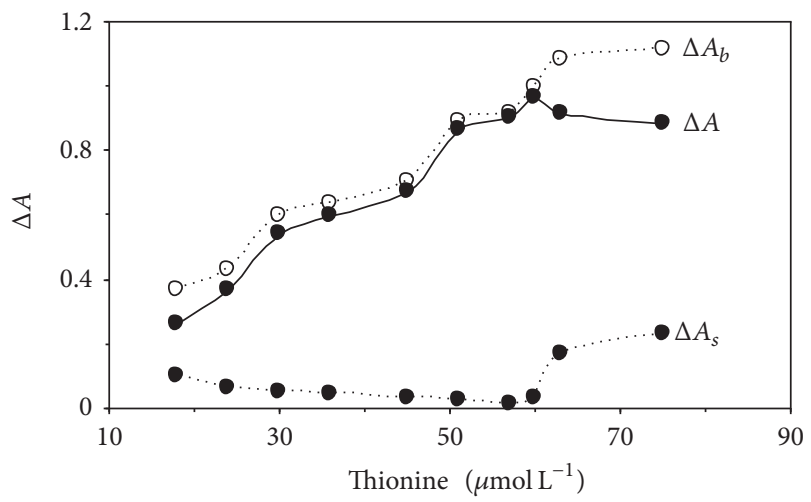

FIGURE 3: Effect of thionine concentration on the rate of uninhibited $\left(\Delta A_{b}\right)$ and inhibited $\left(\Delta A_{s}\right)$ reaction and response $(\Delta A)$. Conditions: sulfuric acid, $0.76 \mathrm{~mol} \mathrm{~L}^{-1}$; bromate, $0.5 \mathrm{mmol} \mathrm{L}^{-1} ; 25^{\circ} \mathrm{C}$ and $4.0 \mathrm{~min}$.

$0.76 \mathrm{~mol} \mathrm{~L}^{-1}$ and decreased at higher concentrations. This may be attributed to protonation of thionine that might stop oxidation or make it quite difficult to occur. Therefore, $0.76 \mathrm{~mol} \mathrm{~L}^{-1}$ was selected as the optimum concentration of sulfuric acid.

The effect of thionine concentration was studied in the range from $18.0-75.0 \mu \mathrm{mol} \mathrm{L}^{-1}$ at $0.76 \mathrm{~mol} \mathrm{~L}^{-1}$ of $\mathrm{H}_{2} \mathrm{SO}_{4}$ (Figure 3). According to Figure 3 , the sensitivity was increased with increasing the thionine concentration up to $60.0 \mu \mathrm{mol} \mathrm{L}$. Thus, $60.0 \mu \mathrm{mol} \mathrm{L}^{-1}$ was selected as the optimum value for thionine.

Under the optimum concentrations of sulfuric acid and thionine, the effect of bromate concentration was investigated over the range from $0.25-0.55 \mathrm{mmol} \mathrm{L}^{-1}$ (Figure 4). As it can be seen in Figure 4, the maximum response was obtained at $0.4 \mathrm{mmol} \mathrm{L}^{-1}$ of bromate concentration. Therefore, this concentration was selected for further study.

Under the optimum reagents concentration, the effect of the ionic strength was studied in the range from $0.00-0.75 \mathrm{~mol} \mathrm{~L}^{-1}$ by using a sodium sulfate solution $\left(3.0 \mathrm{~mol} \mathrm{~L}^{-1}\right)$. The experimental results show that the response was not varied regularly with increasing the sodium

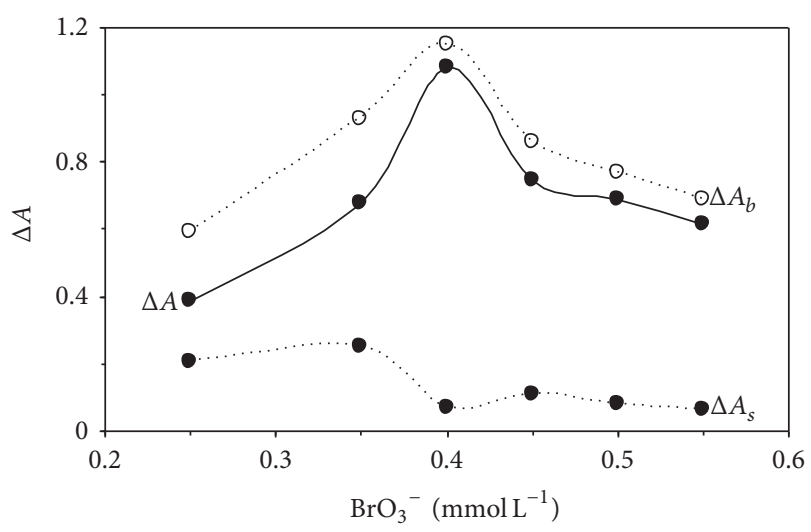

FIGURE 4: Effect of bromate concentration on the rate of uninhibited $\left(\Delta A_{b}\right)$ and inhibited $\left(\Delta A_{s}\right)$ reaction and response $(\Delta A)$. Conditions: sulfuric acid, $0.76 \mathrm{~mol} \mathrm{~L}^{-1}$; thionine, $60.0 \mu \mathrm{mol} \mathrm{L}^{-1} ; 25^{\circ} \mathrm{C}$ and $4.0 \mathrm{~min}$.

TABLE 1: Tolerance limit for various species for the determination of $1.0 \mu \mathrm{g} \mathrm{mL}^{-1}$ of hydrazine.

\begin{tabular}{lc}
\hline Foreign species & $\begin{array}{c}\text { Tolerance limit } \\
\left(w_{\text {species }} / w_{\text {hydrazine }}\right)\end{array}$ \\
\hline $\mathrm{EDTA}$, sulfamic acid & 1000 \\
$\mathrm{Li}^{+}, \mathrm{Na}^{+}, \mathrm{K}^{+}, \mathrm{Ca}^{2+}, \mathrm{Mg}^{2+}$ & 1000 \\
$\mathrm{NO}_{3}{ }^{2+}, \mathrm{SO}_{4}{ }^{2-}, \mathrm{PO}_{4}{ }^{3-}, \mathrm{CH}_{3} \mathrm{CO}_{2}{ }^{-}, \mathrm{CO}_{3}{ }^{2-}, \mathrm{HCO}_{3}{ }^{-}$ & 1000 \\
${ }^{\mathrm{a}} \mathrm{Fe}^{3+}, \mathrm{Cr}^{3+}, \mathrm{Zn}^{2+}$ & 950 \\
${ }^{\mathrm{b}} \mathrm{NO}_{2}{ }^{-}$ & 760 \\
${ }^{\mathrm{a}} \mathrm{Fe}^{2+}$ & 600 \\
$\mathrm{Cl}^{-}$ & 50
\end{tabular}

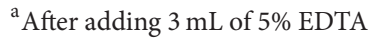

${ }^{\mathrm{b}}$ After adding $3 \mathrm{~mL}$ of $3 \%$ sulfamic acid.

sulfate concentration and the most sensitivity was obtained in absence of it. This may be attributed to the absorption behavior of thionine. In presence of sodium sulfate, the closeness of ions to thionine alters the molar absorptivity of it due to electrostatic interactions. Therefore, the effect of this parameter was overlooked.

The influence of temperature on the reaction rate was studied in the range from $15-45^{\circ} \mathrm{C}$ with the obtained optimum conditions. The results in Figure 5 show a maximum at $20^{\circ} \mathrm{C}$. Therefore, this value was selected as the optimum temperature.

The optimum time of reaction was found by measuring the change in the absorbance from $0.5-4.0 \mathrm{~min}$. The reaction rate increased up to $2.5 \mathrm{~min}$, and in longer times it was almost constant. Therefore, $2.5 \mathrm{~min}$ was selected as the optimum value.

3.2. Analytical Parameters. Under optimum conditions (sulfuric acid: $0.76 \mathrm{~mol} \mathrm{~L}^{-1}$; thionine: $60.0 \mu \mathrm{mol} \mathrm{L}^{-1}$; bromate: $0.4 \mathrm{mmol} \mathrm{L}^{-1}$; temperature: $20^{\circ} \mathrm{C}$; time: $2.5 \mathrm{~min}$ ), a linear calibration curve was obtained over the concentration range from $0.8-23.0 \mu \mathrm{gL}^{-1}$ of hydrazine including two linear 
TABLE 2: Comparison of some analytical parameters of catalytic spectrophotometric methods to proposed method.

\begin{tabular}{|c|c|c|c|c|c|c|}
\hline Reaction system & Method & Effect on reaction system & L.R. $\left(\mu \mathrm{g} \mathrm{mL}^{-1}\right)$ & D.L. $\left(\mu \mathrm{g} \mathrm{mL}^{-1}\right)$ & Sample & Ref. \\
\hline $\mathrm{Mo}(\mathrm{VI})-\mathrm{HCl}$ & Fixed time & Inhibitory & $3.2-448.0$ & 1.0 & Not applied & [21] \\
\hline Neutral red- $\mathrm{NO}_{2}{ }^{-}$ & Fixed time & Inhibitory & $0.15-0.99$ & 0.1 & Water & {$[22]$} \\
\hline $\mathrm{HCl}-\mathrm{BrO}_{3}^{-}$ & Fixed time & Inhibitory & $0.0096-1.02$ & 0.0027 & Water & [24] \\
\hline Thionine- $\mathrm{BrO}_{3}^{-}$ & Fixed time & Inhibitory & $0.8-23.0$ & 0.22 & Water and cooling tower water & This work \\
\hline
\end{tabular}

TABLE 3: The recovery results on the determination of hydrazine in the different water samples using the proposed method and the standard ASTM method.

\begin{tabular}{|c|c|c|c|c|c|c|c|}
\hline \multirow{3}{*}{ Sample } & \multicolumn{7}{|c|}{ Hydrazine $\left(\mu \mathrm{g} \mathrm{mL}^{-1}\right)$} \\
\hline & \multicolumn{3}{|c|}{ Proposed method } & \multicolumn{3}{|c|}{ ASTM method } & \multirow{2}{*}{$\begin{array}{c}\text { Statistical test } \\
t \text { test }^{\mathrm{b}}\end{array}$} \\
\hline & Added & Found $^{\mathrm{a}}$ & Recovery (\%) & Added & Found $^{\mathrm{a}}$ & Recovery (\%) & \\
\hline \multirow{2}{*}{ Distilled water } & 1.0 & $1.01 \pm 0.01$ & 102.0 & 1.0 & $0.99 \pm 0.01$ & 99.0 & 3.40 \\
\hline & 5.0 & $4.98 \pm 0.05$ & 99.6 & 5.0 & $5.01 \pm 0.03$ & 100.2 & 1.04 \\
\hline \multirow{2}{*}{ Drinking water } & 1.0 & $0.99 \pm 0.03$ & 99.0 & 1.0 & $1.01 \pm 0.01$ & 101.0 & 1.15 \\
\hline & 5.0 & $5.03 \pm 0.04$ & 100.6 & 5.0 & $4.98 \pm 0.05$ & 99.6 & 2.16 \\
\hline \multirow{4}{*}{ Cooling tower water (1) } & - & $2.12 \pm 0.02$ & & - & $2.09 \pm 0.02$ & & 2.59 \\
\hline & 1.0 & $3.14 \pm 0.03$ & 100.6 & 1.0 & $3.08 \pm 0.03$ & 98.7 & 3.46 \\
\hline & 5.0 & $7.05 \pm 0.08$ & 99.0 & 5.0 & $7.15 \pm 0.08$ & 102.4 & 2.16 \\
\hline & 15.0 & $17.19 \pm 0.15$ & 100.4 & 15.0 & $17.38 \pm 0.18$ & 101.7 & 2.19 \\
\hline \multirow{3}{*}{ Cooling tower water (2) } & - & $2.25 \pm 0.02$ & & - & $2.27 \pm 0.02$ & & 1.73 \\
\hline & 10.0 & $12.19 \pm 0.11$ & 99.5 & 10.0 & $12.28 \pm 0.12$ & 100.9 & 1.42 \\
\hline & 20.0 & $22.31 \pm 0.21$ & 100.3 & 20.0 & $22.08 \pm 0.19$ & 99.6 & 1.89 \\
\hline
\end{tabular}

aean \pm standard deviation $(n=3)$.

${ }^{\mathrm{b}}$ Tabulated $t$-value for three replicate determinations at $P(0.95)$ is 4.30 .

segments of $0.8-6.0$ and $6.0-23.0 \mu \mathrm{g} \mathrm{mL}^{-1}$. The data analysis gave the regression equations for the first and second linear segments of (3) as follows:

$$
\begin{array}{ll}
\Delta A=0.1393[C]+0.0074 & \left(R^{2}=0.9994\right) \\
\Delta A=0.0312[C]+0.6576 & \left(R^{2}=0.9996\right)
\end{array}
$$

where $\Delta A$ is the difference in the absorbance changes between the blank and sample (response), $C$ is the concentration of hydrazine $\left(\mu \mathrm{g} \mathrm{mL}^{-1}\right)$, and $R^{2}$ is the correlation coefficient.

The relative standard deviation of five replicate determinations was $0.74 \%$ for a solution of $1.0 \mu \mathrm{g} \mathrm{mL}^{-1}$ of hydrazine. The detection limit, defined as D.L. $=3 s_{b} / m$, where $s_{b}$ is standard deviation of the blank signal and $m$ is the slope of the calibration curve, was $0.22 \mu \mathrm{g} \mathrm{mL}^{-1}$ of hydrazine.

To study the selectivity of the proposed method, the effect of various species on the determination of $1.0 \mu \mathrm{g} \mathrm{mL}$ of hydrazine was investigated (Table 1). The tolerance limit was defined as the concentration of added species causing a relative error less than $5 \%$. As it can be seen in Table 1, most of species did not interfere even when present in 100-fold excess over hydrazine.

In Table 2, some of the analytical parameters obtained in this work are compared with those previously reported in the literature [21, 22, 24]. According to Table 2, the proposed method is comparable to other catalytic kinetic spectrophotometric methods. Therefore, the proposed method has the

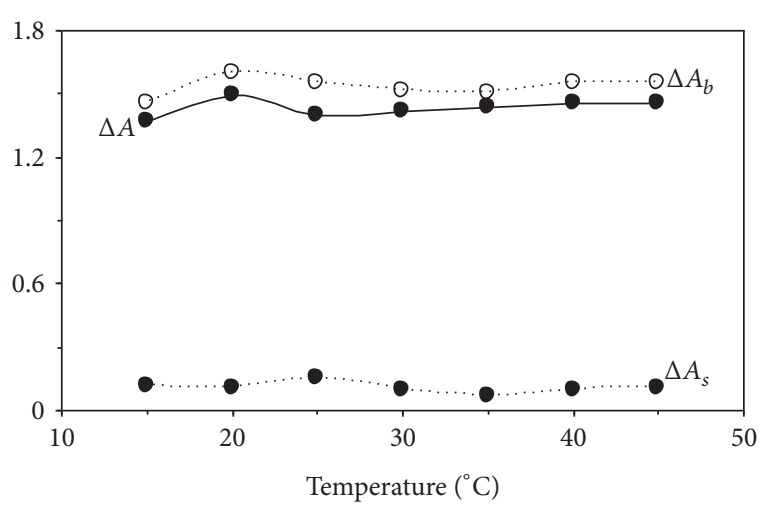

FIGURE 5: Effect of temperature on the rate of uninhibited $\left(\Delta A_{b}\right)$ and inhibited $\left(\Delta A_{s}\right)$ reaction and response $(\Delta A)$. Conditions: sulfuric acid, $0.76 \mathrm{~mol} \mathrm{~L}^{-1}$; thionine, $60.0 \mu \mathrm{mol} \mathrm{L}^{-1}$; bromate, $0.4 \mathrm{~mol} \mathrm{~L}^{-1}$; and $4.0 \mathrm{~min}$.

potential to offer itself as an alternative method for hydrazine analysis.

3.3. Application. In order to evaluate the capability of the proposed method, it was applied to the determination of hydrazine in different water samples. For this purpose, four water samples from three sources were examined. The distilled water and drinking water were spiked with $1.0 \mu \mathrm{g} \mathrm{mL}^{-1}$ and $5.0 \mu \mathrm{g} \mathrm{mL}^{-1}$ of hydrazine. Cooling tower water samples 
were prepared from Yazd Power Generation Co and analysed as received. The obtained results were given in Table 3. The recoveries $(n=3)$ were between 98.0 and $103.4 \%$ that confirm the reliability of the proposed method. Also, the same samples were analysed using ASTM method [25]. The recoveries vary over the range 98.7-102.4\% for ASTM method. As it can be seen, the recoveries obtained from the two methods are in good agreement together. Moreover, the $t$-test for three replicate determinations at 95\% confidence limit did not show a significant difference between the results obtained from the two methods.

\section{Conclusion}

A simple, selective and sensitive kinetic spectrophotometric method for the determination of hydrazine was developed based on its inhibitory effect on the oxidation of thionine with bromate in the acidic media. The method was suitable for the determination of hydrazine in different water samples with satisfactory results.

\section{References}

[1] H. M. Nassef, A. E. Radi, and C. K. O’Sullivan, "Electrocatalytic oxidation of hydrazine at o-aminophenol grafted modified glassy carbon electrode: reusable hydrazine amperometric sensor," Journal of Electroanalytical Chemistry, vol. 592, no. 2, pp. 139-146, 2006.

[2] S. M. Golabi and H. R. Zare, "Electrocatalytic oxidation of hydrazine at a chlorogenic acid (CGA) modified glassy carbon electrode," Journal of Electroanalytical Chemistry, vol. 465, no. 2, pp. 168-176, 1999.

[3] A. A. Ensafi and E. Mirmomtaz, "Electrocatalytic oxidation of hydrazine with pyrogallol red as a mediator on glassy carbon electrode," Journal of Electroanalytical Chemistry, vol. 583, no. 2, pp. 176-183, 2005.

[4] E. R. Riegel, Riegel's Handbook of Industrial Chemistry (1992), Kluwer Academic/Plenum Publishers, New York, NY, USA, 2003.

[5] M. Mori, K. Tanaka, Q. Xu, M. Ikedo, H. Taoda, and W. $\mathrm{Hu}$, "Highly sensitive determination of hydrazine ion by ionexclusion chromatography with ion-exchange enhancement of conductivity detection," Journal of Chromatography A, vol. 1039, no. 1-2, pp. 135-139, 2004.

[6] H. Kirchherr, "Determination of hydrazine in human plasma by high-performance liquid chromatography," Journal of Chromatography, vol. 617, no. 1, pp. 157-162, 1993.

[7] W. Siangproh, O. Chailapakul, R. Laocharoensuk, and J. Wang, "Microchip capillary electrophoresis/electrochemical detection of hydrazine compounds at a cobalt phthalocyanine modified electrochemical detector," Talanta, vol. 67, no. 5, pp. 903-907, 2005.

[8] H. R. Zare, M. R. Shishehbore, D. Nematollahi, and M. S. Tehrani, "Electrochemical behavior of nano-composite containing 4-hydroxy-2- (triphenylphosphonio)phenolate and multi-wall carbon nanotubes spiked in carbon paste and its application for electrocatalytic oxidation of hydrazine," Sensors and Actuators B, vol. 151, no. 1, pp. 153-161, 2010.

[9] G. Wang, C. Zhang, X. He et al., "Detection of hydrazine based on Nano-Au deposited on Porous-TiO2 film," Electrochimica Acta, vol. 55, no. 24, pp. 7204-7210, 2010.
[10] A. M. H. Shabani, S. Dadfarnia, and K. Dehghan, "Indirect spectrophotometric determination of trace quantities of hydrazine," Bulletin of the Korean Chemical Society, vol. 25, no. 2, pp. 213-215, 2004.

[11] A. A. Ensafi and B. Naderi, "Flow injection determination of hydrazine with fluorimetric detection," Talanta, vol. 47, no. 3 , pp. 645-649, 1998.

[12] J. Lv, Y. Huang, and Z. Zhang, "Determination of hydrazine by flow injection with chemiluminescence," Analytical Letters, vol. 34 , no. 8, pp. 1323-1330, 2001.

[13] E. Athanasiou-Malaki and M. A. Koupparis, "Kinetic study of the determination of hydrazines, isoniazid and sodium azide by monitoring their reactions with 1-fluoro-2,4-dinitrobenzene, by means of a fluoride-selective electrode," Talanta, vol. 36, no. 4, pp. 431-436, 1989.

[14] S. Ikeda, H. Sutake, and Y. Kohri, "Flow injecton analysis with amperometric detector utilizing the redox reaction of iodate ion," Chemistry Letters, vol. 13, no. 6, pp. 873-876, 1984.

[15] A. Sheibani, M. R. Shishehbore, and Z. T. Ardakani, "Kinetic spectrophotometric determination of bromide in clidinium-c drug," Chinese Chemical Letters, vol. 22, no. 5, pp. 595-598, 2011.

[16] M. R. Shishehbore, A. Sheibani, and E. Mirparizi, "A new kinetic spectrophotometric method for the determination of major metabolite of heroin in biological," Chinese Chemical Letters, vol. 23, no. 5, pp. 611-614, 2012.

[17] M. R. Shishehbore and R. Jokar, "A kinetic spectrophotometric method for vanadium $(\mathrm{V})$ determination in food samples using a Janus Green-bromate system," Analytical Methods, vol. 3, no. 1, pp. 2815-2821, 2011.

[18] A. A. Ensafi and M. A. Chamjangali, "Flow injection spectrophotometric determination of trace amounts of hydrazine by the inhibition of the pyrogallol red-iodate reaction," Journal of Analytical Chemistry, vol. 59, no. 2, pp. 129-133, 2004.

[19] A. A. Ensafi and B. Naderi, "Flow-injection spectrophotometric determination of hydrazine," Microchemical Journal, vol. 56, no. 3, pp. 269-275, 1997.

[20] M. I. Evgen'yev, S. Y. Garmonov, I. I. Evgen'yeva, and H. C. Budnikov, "Determination of hydrazine derivatives by flowinjection analysis with spectrophotometric detection," Talanta, vol. 42, no. 10, pp. 1465-1469, 1995.

[21] A. Safavi and A. A. Ensafi, "Kinetic spectrophotometric determination of hydrazine," Analytica Chimica Acta, vol. 300, no. 1-3, pp. 307-311, 1995.

[22] S. Wang, L. Du, A. Zhang, and D. Liu, "Kinetic spectrophotometric determination of hydrazine with neutral red-nitrite system," Mikrochimica Acta, vol. 134, no. 3-4, pp. 167-170, 2000.

[23] M. George, K. S. Nagaraja, and N. Balasubramanian, "Spectrophotometric determination of hydrazine using bromine and methyl red," Indian Journal of Chemistry, vol. 46, no. 10, pp. 1621-1624, 2007.

[24] A. Afkhami and A. Afshar-E-Asl, "Kinetic-spectophotometric determination of hydrazine by the inhibition of the bromatehydrochloric acid reaction," Analytica Chimica Acta, vol. 419, no. 1, pp. 101-106, 2000.

[25] ASTM D, 1385-01 standard method for hydrazine in water. 

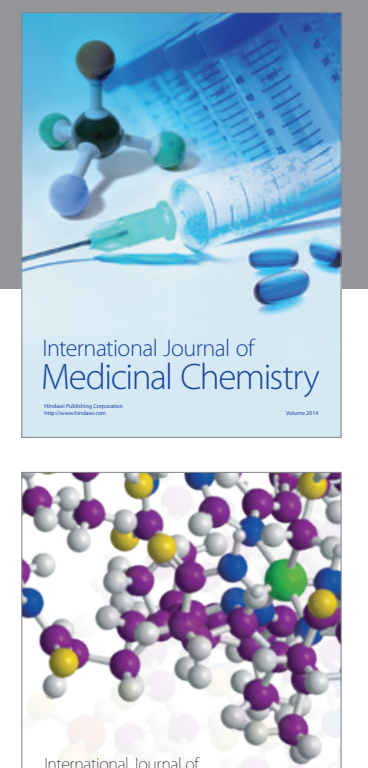

\section{Carbohydrate} Chemistry

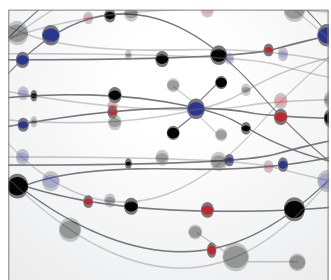

The Scientific World Journal
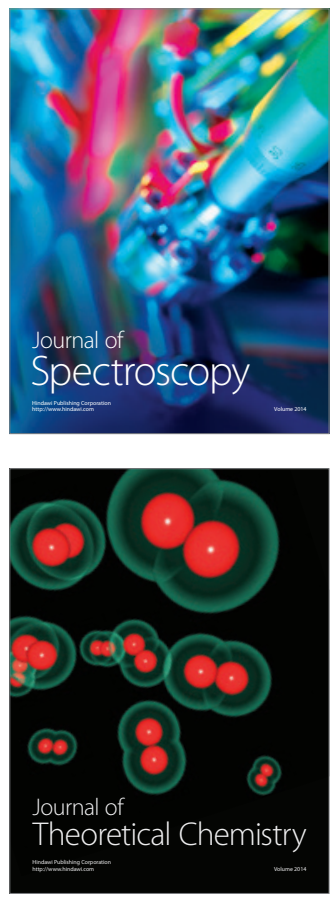
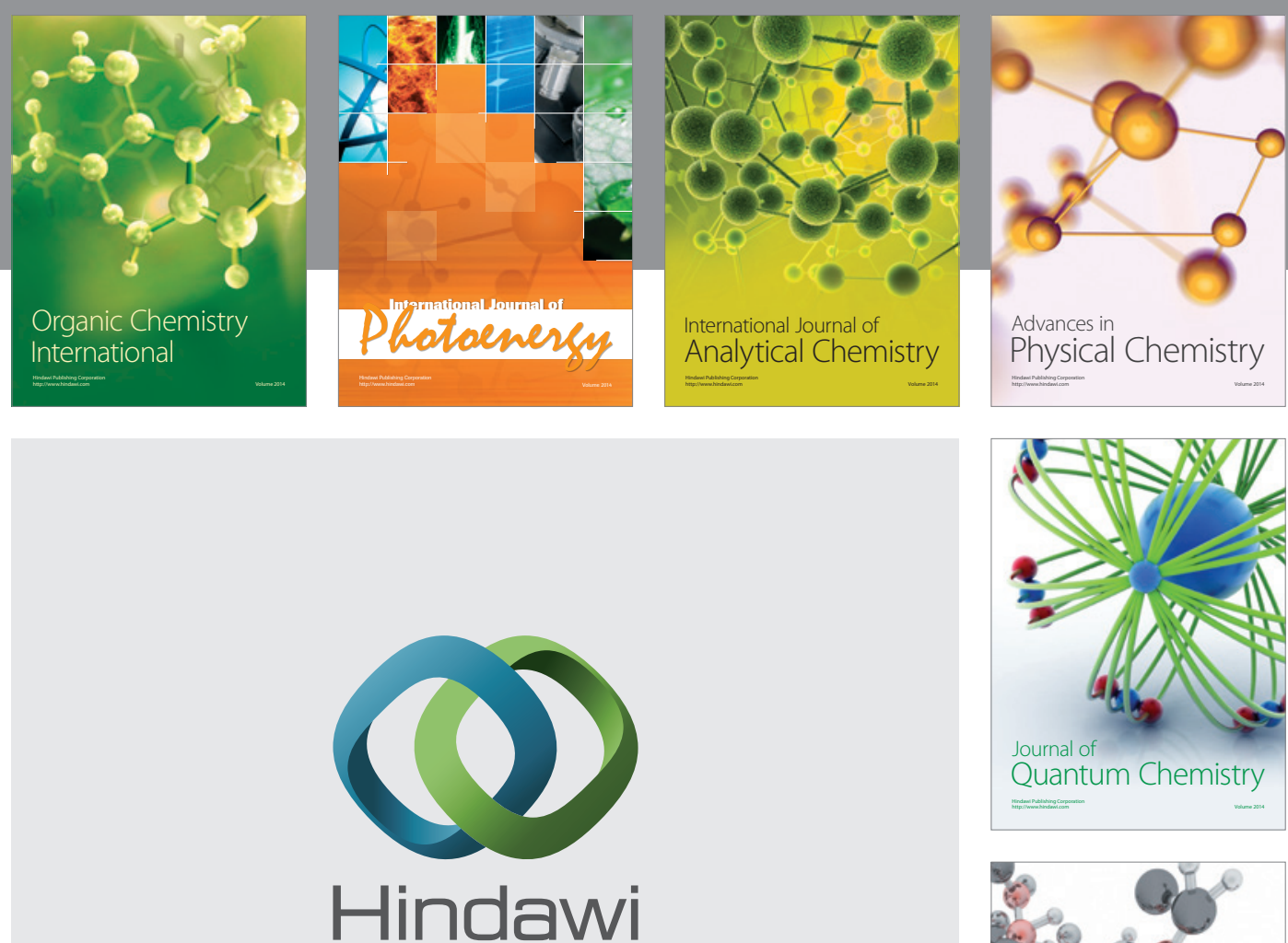

Submit your manuscripts at

http://www.hindawi.com

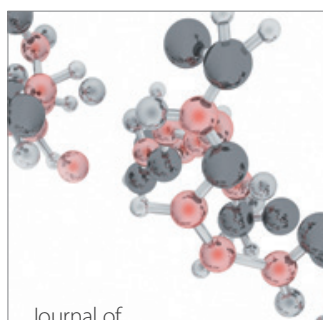

Analytical Methods

in Chemistry

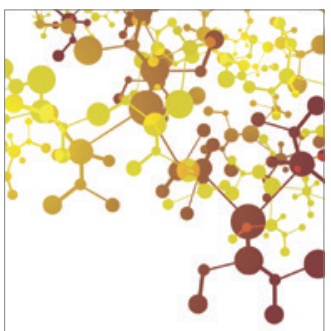

Journal of

Applied Chemistry

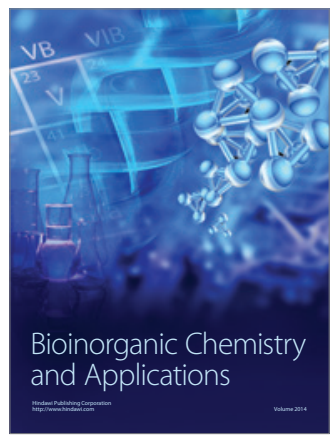

Inorganic Chemistry
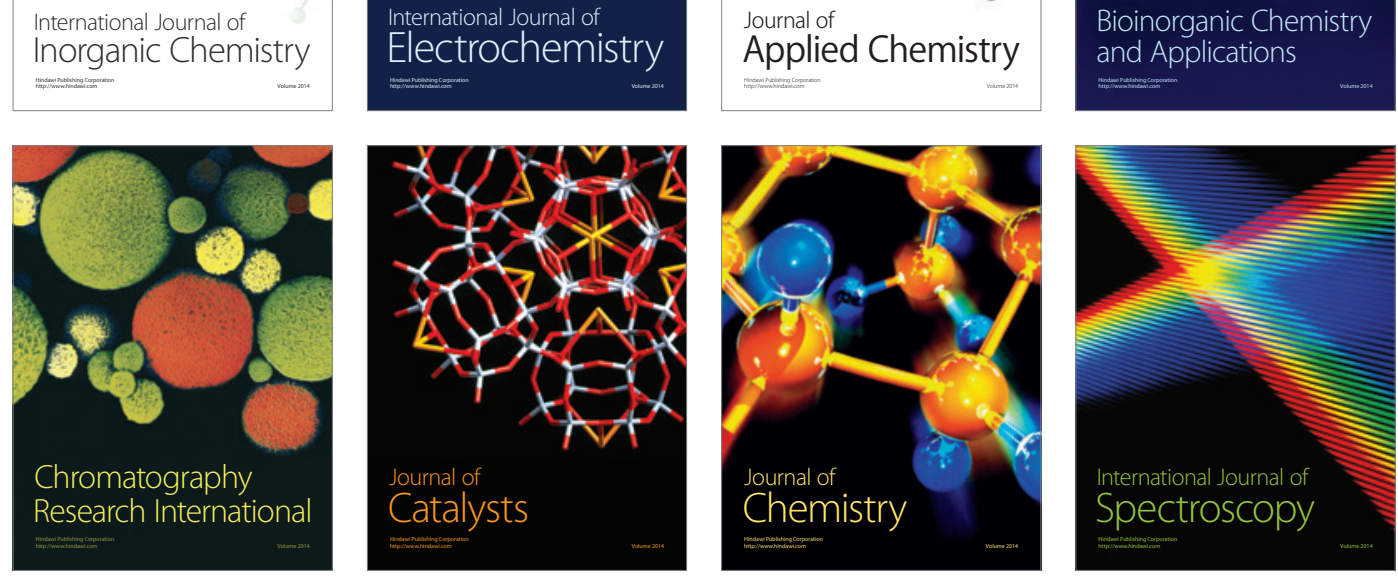